409. 加温用テフロンコーティング針の開発

\title{
Development of Teflon-coated needle for hyperthermia
}

\author{
大阪市立総合医療センター中央放射線部 ○黒田啓史 菱田武 山崎昭作 \\ 大江公明 堀内承治 山西弘朗 泉谷信行 \\ 山本ビニター \\ 山本五郎
}

【【目的】ハイパーサーミアにおいて、小線源組織内照射後、病巣部に刺入された針を、陰電極針として利用し加" 温すれば、局所に有効な効果が得られると考え、テフロンコーティング針を試作し，加温実験を行った。

【原理】2枚の平板電極で、小線源治療針を刺入した誘電体をはさみ、高周波を加える。針先端のテフロンコー ティングされていない金属部分が、陰電極として作用し、周囲への電磁波の収束性を高め、ジュール熱によって 局所の温度が上昇する。(刺入電極から電磁波を輻射せずに電磁波を集束させる。)

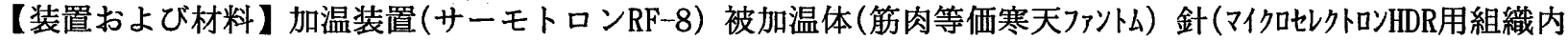
刺入針の、先端部を除いて厚さ0.02mmのテフロンコーティングを施したもの。）導電線(外径 $1.5 \mathrm{~mm}$ 長さ $3.5 \mathrm{~m}$ 針の尾部に接続） 温度計-熱電対温度計(銅一エンスタタタ)

【実験】11 温熱治療に必要な温度上昇率が得られるかを調べた。ファントムに陰電極部1cm針を刺入し尾部に 導電線を接続した。出力 $300 \mathrm{w} て ゙ 15$ 分間加温し針管内および針から $0 \mathrm{~mm} 5 \mathrm{~mm} 10 \mathrm{~mm}$ 温度計測した。(Fig.1) 針の 近傍では $8^{\circ} \mathrm{C} 、 10 \mathrm{~mm}$ 離れた位置では $6.5^{\circ} \mathrm{C}$ の温度上昇が得られた。

2 針5本を $2 \mathrm{~cm}$ 間隔平行に刺入し,各針管内の温度変化をしらべた。5分までのばらつきは各針のアース効率が 違うために起こり、5分以降アースを整えると、ほぼ同じ上昇率となった。(Fig.2)

3. 出力一定で針数別 $(2 \sim 5$ 本 $)$ の温度上昇率をしらべた。針数と出力は温度上昇率に関係し,針を增やすと集束 される電磁波が分散され温度上昇率が下がった。(Fig.3)

4 針5本を $2 \mathrm{~cm}$ 間隔に刺入し、加温後アキシャル断面をサーモグラフィー撮影した。(Fig.4) $42.5^{\circ} \mathrm{C} \sim 45^{\circ} \mathrm{C}$ 黒 く塗りつぶし有効加温範囲として広がりを計測した。縦 $4.6 \mathrm{~cm}$ 横 $5.4 \mathrm{~cm}$ であった。

5 先端金属部の長さ $3 \mathrm{~cm}$ と $5 \mathrm{~cm}$ の針を加温後、平行断面をサーモグラフィー撮影した。(Fig.5) 金属長 $3 \mathrm{~cm}$ では 針軸方向に $4 \mathrm{~cm}$ 横方向に $2.4 \mathrm{~cm} 、$ 金属長 $5 \mathrm{~cm}$ では、針軸方向に $6 \mathrm{~cm}$ 横方向に $2.7 \mathrm{~cm}$ 有効加温範囲であった。
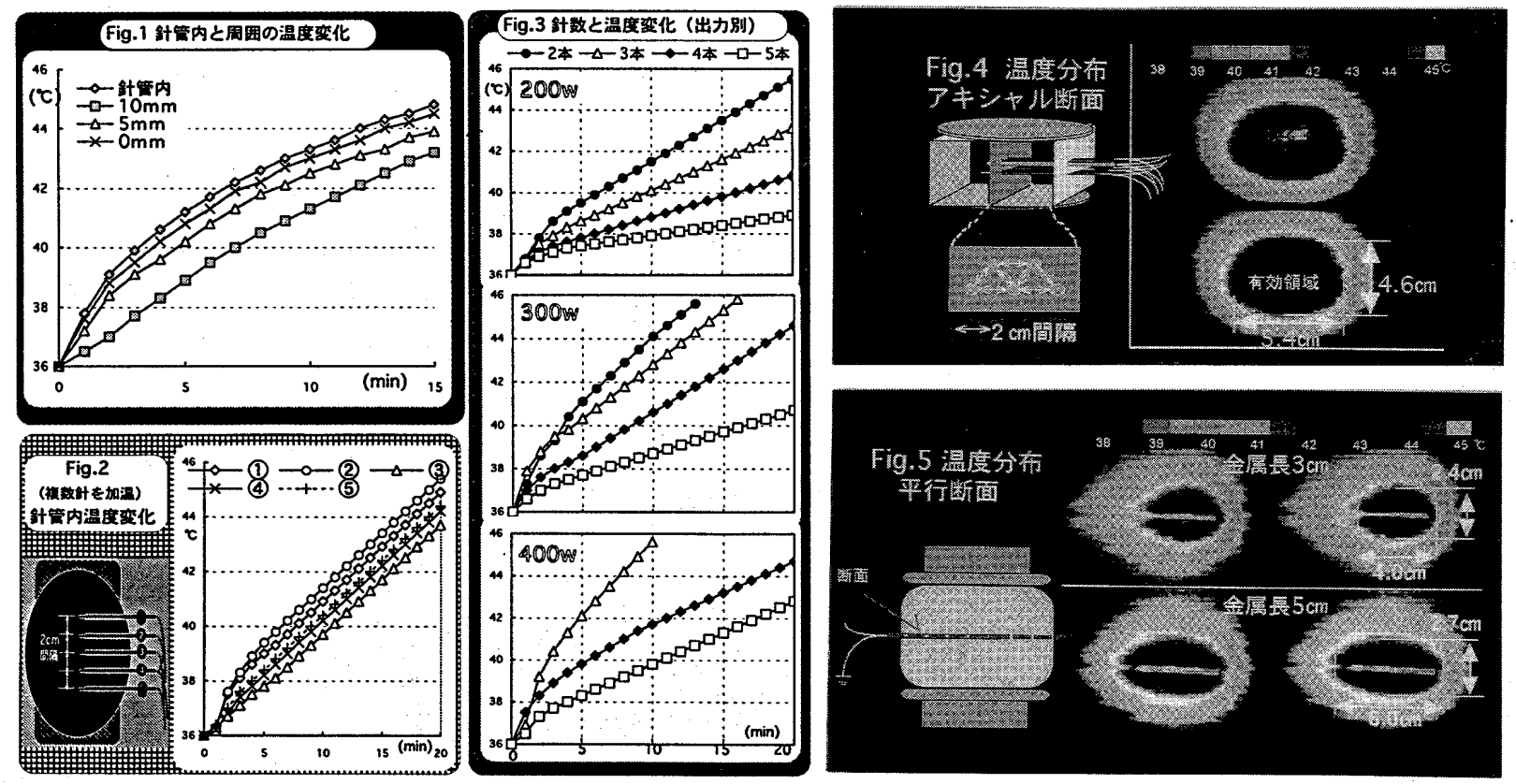

【結果】11 良好な温度上昇率が得られた。2 複数の針を平行に並べての加温では位置による変化率に差は少 ないが、アース効率を整える必要があった。る 針数を增やすと陰電極針一本当たりに集束される電磁波が分散 され温度上昇率が下がった。4 針を複数使用、または先端部の長さを变えることで立体的な加温ができた。

【まとめ】テフロンコーティング針を使用しての加温は小線源治療と併用ができ、かつ局所加温に適している と考えられた。 